there is a liability that copious and apparently highly accurate results may be amassed which are actually unreliable. Other devices listed include Bay and Steiner's hydrogen discharge tubes for providing continuous ultra-violet sources of light, and also a micrometer liquid cell for studying the absorption of thin layers of liquid.

\section{Biology in Shakespeare}

IT would be indeed a difficult problem to conceive of any new point of view from which to study Shakespeare's works. In the Scientific Monthly for January, Prof. Fraser-Harris has made a study of the world's greatest poet and dramatist from the point of view of biology, and though the topic is not a new one-there is a public garden in Manchester where nearly all the plants, wild and cultivated, mentioned in Shakespeare are grown, and references given-the method is new, in that Prof. FraserHarris has aimed, not at giving a catalogue of plants and animals, but at considering a few allusions which are of distinctly physiological or psychological interest. For example, Prof. Fraser-Harris claims four participating factors in sleep-chemical, vascular, sensory, and ideational; and Shakespeare recognises two of these in the famous soliloquy of the king in "Henry IV". Although Shakespeare was a contemporary of Harvey, there is no reference in his works to blood circulation, and though one might express surprise at this, Prof. Fraser-Harris gives sufficient argument why Shakespeare was ignorant of the then new discovery. These are only two examples of how Shakespearean lines embody deep biological truths ; many more, with the appropriate quotations and commentaries, are given by Prof. Fraser-Harris in his interesting article.

\section{Veterinary Research in South Africa}

WE have received the seventeenth report of the Director (Prof. P. J. du Toit) of Veterinary Services and Animal Industry, Onderstepoort, Pretoria (Union of S. Africa : Dep. of Agriculture. The Government Printer, Pretoria, 1931. 10s. each part). It is issued in two parts of about 425 pages each, is well produced and fully illustrated, and contains a mass of valuable material dealing with all branches of veterinary research and animal industry. Part 1 contains the parasitological matter, part 2 physiological, pathological, and industrial subjects and metabolism. Of general interest may be mentioned papers on a new and cheap method of preparing pure cystine from wool, and giving a high yield, by J. G. Louw; the good effects of sulphur on merino sheep in doses of $5 \mathrm{gm}$. from once to six times weekly, the general condition of the animals, weight, and wool yield being strikingly improved, by D. G. Steyn; and the improved quality of bacon obtained by including barley meal in the pig's ration, by D. J. Schulte and C. A. Murray.

\section{British Lenses}

We learn from Messrs. Taylor, Taylor and Hobson, Ltd., that they have recently received a contract for no less than 350,000 lenses, totalling more than half a million glasses, for inexpensive hand cameras.
Messrs. Taylor, Taylor and Hobson produce costly Cooke lenses used in some of the world's leading observatories for stellar photography, and also highly corrected Cooke lenses of large aperture for the exacting requirements of the principal cinema studios throughout Britain and the United States. It is the high degree of precision demanded by these more expensive products that has enabled the firm to design and make machinery capable of producing inexpensive lenses in such quantities and in competition with such low Continental prices as those for which the above contract has been awarded.

\section{Eskimo Settlement in Alaska}

AN expedition of the University of Pennsylvania Museum, of which Miss Frederica de Laguna is the leader, working in Alaska during the past season, reports the discovery, according to Science Service, of a prehistoric Eskimo settlement at Cook's Inlet. This area is at present inhabited by Indians, and the settlement would appear to represent the most southerly extension of Eskimo culture known. Shell heaps on the shore, some of them ten to fourteen feet in height, have been investigated. Among the relics were a number of personal ornaments, including lip plugs, beads, an ivory pendant, a carved ivory head, and a nose-pin. The objects of domestic use included a lamp, a needle-case and needles, and an ivory catch for a box. One of the most interesting relics was a mirror of slate, of which the surface showed the reflection on being damped.

\section{Esperanto in Scientific Literature}

REFERRING to the recent correspondence in NATURE on Esperanto in scientific literature, Prof. W. E. Collinson, professor of German and John Buchanan lecturer in Esperanto in the University of Liverpool, has written stating that the fullest and most extensively documented account of such writings is Section 86 of Dr. Eugen Wüster's "Internationale Sprachnormung in der Technik-besonders in der Elektrotechnik" (published with the support of the Akademie des Bauwesens, VDI-Verlag, Berlin, 1931). This work deals with the problem of the international standardisation of technical nomenclature in all its aspects, and shows the wide range of topies in which work has already appeared in Fsperanto, namely, biochemistry, strength of materials, inorganic and organic chemistry, telephony and wireless, bacteriology, analytical geometry, etc.

\section{Postponement of an International Congress}

WE learn from the General Secretary, Prof. E. Moles, San Barnado 49, Madrid, that at a meeting of the Bureau of the International Union of Chemistry and the organising committee of the Ninth International Congress of Pure and Applied Chemistry held recently, it was decided to postpone the Congress indefinitely. The Congress was to have been at Madrid on April 3-10 this year, but it was felt that the present world-wide economic depression would limit seriously the usefulness of such a gathering. When conditions improve it is hoped to hold the Congress as originally arranged at Madrid.

(Continued on p. 241.)

No. 3250, VoL. 129] 


\section{Announcements}

Trte annual Sir John Rhŷs Memorial Lecture of the British Academy will be delivered on Feb. 17 by Prof. H. J. Fleure, professor of geography in the University of Manchester, who will take as his subject "Archæology and Folk-Tradition".

THE ninety-first annual general meeting of the Chemical Society will be held in Glasgow on March 18, under the presidency of Prof. G. G. Henderson, regius professor of chemistry in the University of Glasgow, who will take as the subject for his address "The Publication of Chemical Literature". This will be the first official visit of the Sociesty to Scotland.

The Right Hon. Lord Plender; Mr. Bertram S. Thomas, Arabian explorer and orientalist; and the Rev. A. T. P. Williams, headmaster of Winchester College, have been elected members of the Athenæum under the provisions of Rule II. of the Club, which empowers the annual election by the committee of a certain number of persons of distinguished eminence in science, literature, the arts, or for public services.

THE Langley Prize, which is usually awarded every three years for the best paper submitted by officers of the West African Medical Service-whether on the active or retired list-has been awarded by the London School of Hygiene and Tropical Medicine in equal shares for Dr. E. C. Smith's paper "A Dermatological Atlas of Nigeria" and for Dr. Hope Gill's paper "Diagnostic Methods in Human Trypanosomiasis".

THE following appointments in the Colonial Agricultural Service have recently been made by the Secretary of State for the Colonies: Mr. G. E. Bodkin, Government entomologist, Palestine, to be director of agriculture, Mauritius ; Mr. A. S. Thomas, economic botanist, Gold Coast, to be assistant botanist, Uganda ; Mr. J. E. P. Booth, to be agricultural officer, Kenya; Mr. R. E. T. Hobbs, to be agrieultural officer, Kenya; Mr. W. T. Dalgarno, to be agricultural instructor, Bahamas; Mr. J. C. Eyre, to be district agricultural officer, Tanganyika Territory.

Is view of the present situation, and the recent appointment of Dr. C. P. Blacker as general secretary of the Eugenics Society, the salaried appointment of Mrs. C. B. S. Hodson will terminate next August. Mrs. Hodson is to continue to work in close association with the Society as a member of the council, and so secure the continuation of the eugenic work already begun in different parts of Great Britain. This arrangement leaves unaffected Mrs. Hodson's position as honorary administrative secretary to the International Federation of Eugenic Organizations, and she retains her place on the Committee for Legalising Eugenic Sterilization.

Owing to the closing of Chillingham Castle, Northumberland, efforts are being made to keep together the famous herd of wild cattle which is believed to have roamed in the castle enclosure since the thirteenth century. It is announced in the Times of Feb. 8 that the Zoological Society of London has undertaken to contribute $£ 100$ a year for seven years if a lease at $£ 500$ a year for that period is granted to three trustees nominated by the Society. The remainder of the $£ 500$ a year is to be provided by public subscription. The trustees are Lord Grey of Fallodon, Mr. Hugh S. Gladstone, and Sir Peter Chalmers Mitchell. A public appeal will shortly be made.

WE have received List No, 23, January 1932, of Eastman Organic Chemicals, from the Eastman Kodak Co., Rochester, New York. This contains the names of a large number of special chemicals already available, and also several additions, the specification of which occupies six pages of the catalogue. The prices of all the chemicals are given, and a valuable feature of the list is the inclusion of the physickl constants of nearly all the chemicals.

Mr. C. R. S. Manders suggests in a letter to the Editor that a magnetic field might produce a marked change in the specific inductive capacity of substance. The suggestion is fairly obvious, but no references are given to work upon the subject; and as Mr. Manders gives no address, we are unable to return his letter.

Applications are invited for the following appointments, on or before the dates mentioned:-An assistant secretary of the University of Birmingham - The Secretary, University, Birmingham (Feb, 15). A senior assistant hydrometric engineer in the Civil Engineering Department of the Electricity Supply Board of the Irish Free State-The Secretary, Electricity Supply Board, 60-62 Upper Mount Street, Dublin (Feb. 17). A senior assistant in the library of the University College of Hull-The Registrar, University College, Hull (Feb. 19). An assistant master, mainly for chemistry and physics, at the Acton Technical College-The Principal, Technical College, Acton (Feb. 20). A junior lecturer in the Department of Pathology, University of Liverpool - The Professor of Pathology, University, Liverpool (Feb. 21). A lecturer in engineering at the Wigan and District Mining and Technical CollegeThe Principal, Wigan and District Mining and Technical College, Wigan (Feb. 22). A head of the Department of Industrial and Fine Art, Loughborough College-- The Registrar, Loughborough College, Loughborough (Feb. 26). A principal of the Westminster Technical Institute-The Education Officer (T.1), County Hall, Westminster Bridge, S.E.1 (Feb. 29). A lecturer in experimental pathology and assistant director of cancer research in the University of Leeds - The Registrar, University, Leeds (March 1). A professor of anatomy in the University of Lucknow-The Registrar, Lucknow University, Lucknow, India (March 30). A parttime lecturer in Sinhalese at the School of Oriental Studies--The Secretary, School of Oriental Studies, Finsbury Circus, E.C.2 (April 20). A lecturer in English in the University of Hong Kong--The Secretary, Universities Bureau of the British Empire, 88A Gower Street, W.C.1 (April 30). A professor of agricultural botany in the University of ReadingThe Registrar, University, Reading.

No. 3250, Vor. 129] 